\title{
Amaranthus tricolor crude extract inhibits Cronobacter sakazakii isolated from powdered infant formula
}

\author{
Peng Fei, ${ }^{1 *} \odot$ Hongxia Feng, ${ }^{2 *} \odot$ Yanyan Wang, ${ }^{3}$ Huaibin Kang, ${ }^{1}$ Min Xing,,${ }^{1}$ Yunhe Chang, ${ }^{2} \odot$ Ling Guo, ${ }^{3} \dagger \odot$ \\ and Junliang Chen ${ }^{1} \dagger$ (D) \\ ${ }^{1}$ College of Food and Bioengineering, Henan University of Science and Technology, Luoyang, 471023, China \\ ${ }^{2}$ Food and Pharmaceutical Engineering Institute, Guiyang University, Guiyang 550005, China \\ ${ }^{3}$ Key Laboratory of Dairy Science, Ministry of Education, College of Food Science, Northeast Agricultural University, Harbin, 150030, China
}

\begin{abstract}
The purpose of this study was to elucidate the antibacterial activity and possible mechanism of action of Amaranthus tricolor crude extract (ATCE) against Cronobacter sakazakii isolated from powdered infant formula (PIF). The antibacterial activity of ATCE was assessed by measuring the diameter of inhibition zone (DIZ), minimum inhibitory concentration (MIC), and minimum bactericidal concentration (MBC). The possible mechanism of action of ATCE was revealed by analyzing the effects of ATCE on growth curves and changes in cell membrane potential, intracellular $\mathrm{pH}$, content of bacterial protein and genomic DNA, and cell morphology. Finally, ATCE was applied to the disinfection of C. sakazakii in biofilm on stainless steel tube. The results showed that the DIZ, MIC, and MBC of ATCE against C. sakazakii strains were from $14.35 \pm$ 0.67 to $14.84 \pm 0.67 \mathrm{~mm}, 20 \mathrm{mg} / \mathrm{mL}$, and $40 \mathrm{mg} / \mathrm{mL}$, respectively. Treatment with ATCE ended the logarithmic growth phase of C. sakazakii, and led to depolarization of the cell membranes, reducing intracellular $\mathrm{pH}$ and bacterial protein and genomic DNA contents, and resulting in cytoplasmic leakage and deformation. In addition, ATCE effectively inactivated C. sakazakii in biofilm, reducing viable bacteria by approximately $6.5 \log \mathrm{cfu} / \mathrm{mL}$ bacterial count after treatment with $1 \mathrm{MIC}(1 \mathrm{MIC}=20 \mathrm{mg} / \mathrm{mL})$ of ATCE for $20 \mathrm{~min}$ at $25^{\circ} \mathrm{C}$. Our findings showed that ATCE inactivated $C$. sakazakii strains isolated from PIF and has potential as a natural disinfectant to reduce the contamination of PIF by C. sakazakii.
\end{abstract}

\footnotetext{
Received March 6, 2020.

Accepted June 10, 2020.

*These authors contributed equally to this work.

†Corresponding authors: guoling@neau.edu.cn and junliangchen@ 126.com
}

Key words: Cronobacter sakazakii, Amaranthus tricolor crude extract, powdered infant formula, antibacterial activity

\section{INTRODUCTION}

Cronobacter species, as emerging and opportunistic food-borne pathogens, are gram-negative, motile, nonspore-forming, peritrichous, rod-shaped facultatively anaerobic bacteria (Gurtler et al., 2005; Al-Nabulsi et al., 2009). The genus is diverse and currently divided into 7 species: C. sakazakii, C. malonaticus, C. turicensis, C. muytjensii, C. dublinensis, C. universalis, and C. condimenti (Joseph et al., 2012; Fei et al., 2018b). Among them, C. sakazakii is considered to be the dominant species isolated from powdered infant formula $(\mathbf{P I F})$, and it can cause severe necrotizing enterocolitis, septicemia, and meningitis, with a mortality rate of 40 to $80 \%$ (Caubilla-Barron et al., 2007; Sonbol et al., 2013). Contamination of PIF and its production environments by C. sakazakii are ongoing; for example, Fei et al. $(2015,2017)$ found that the contamination rate of PIF with C. sakazakii in China was $3.5 \%$ in 2009-2012, and 2.8\% from January 2015 to March 2017. Lu et al. (2019) isolated 37 C. sakazakii strains from 835 environmental samples collected from 4 PIF factories. Therefore, it is important to develop and enhance prevention and control measures to reduce the contamination of C. sakazakii strains in PIF.

Some studies have found that C. sakazakii is sensitive to heat and may not survive in PIF after the spray-drying process, although the main points of contamination of this pathogen are primary and secondary packaging (Brandl et al., 2014; Wu et al., 2018). Moreover, C. sakazakii has a strong ability to produce form biofilms that can allow pathogens to stick to the surfaces of stainless steel equipment and various packaging materials, and that play a role in protection of pathogens, resulting in increased resistance to disinfectants and environmental stresses and the risk of contamina- 
tion (Kim et al., 2006; Henry and Fouladkhah, 2019). Cronobacter sakazakii is widely distributed in water, air, and soil; in particular, air is considered the most likely vector for the spread of pathogenic bacteria in PIF factories (Brandl et al., 2014; Fei et al., 2015). Therefore, C. sakazakii strains in the environment need to be strictly controlled during the production process of PIF. Currently, sodium hypochlorite and hydrogen peroxide are the most commonly used disinfectants for environmental sterilization in PIF factories, and longterm use is likely to improve the tolerance of $C$. sakazakii strains to these 2 disinfectants (Park et al., 2016; Kim et al., 2019). In addition, sodium hypochlorite has been banned in some European countries because of its potential harm to the environment (Meireles et al., 2016). In view of this, research is focused on developing environmentally friendly strategies to eliminate $C$. sakazakii in the environment (Shi et al., 2016a,b; Guo et al., 2020a).

Natural products have been widely developed as environmentally friendly potential bacteriostatic agents to inhibit food-borne pathogen contamination in the food industry (Guo et al., 2020a). For example, olive oil polyphenol extract (OOPE) has been shown to have good antibacterial effect on food-borne pathogens, including C. sakazakii, Bacillus cereus, Listeria monocytogenes, Salmonella Typhimurium, and Staphylococcus aureus (Fei et al., 2018a, 2019; Guo et al., 2019, 2020b). Analogously, Amaranthus tricolor and its extract contain alkaloids (betaine), polyphenols (flavonoids, steroids, catechuic acid, and tannins), terpenoids, and saponins, all of which have been reported to have varying degrees of antibacterial activity (Kuete et al., 2011; Peter and Gandhi, 2017). Other species of Amaranthus, including A. viridis, A. hybridus, A. spinosus, and $A$. caudatus, have been confirmed to have a broad spectrum of antibacterial effects (Maiyo et al., 2010; Bulbul et al., 2011). Therefore, there is sufficient evidence that the extract of Amaranthus tricolor should have good antibacterial activity.

Based on the factors described above, we analyzed the antibacterial effect and possible mechanism of $A$. tricolor crude extract (ATCE) against C. sakazakii isolated from PIF. The antibacterial activity of ATCE against $C$. sakazakii was assessed based on the values of diameter of inhibition zone (DIZ), MIC, and minimal bactericidal concentration (MBC). We demonstrated the effects of ATCE on the growth curves of C. sakazakii and clarified the mechanism of action of ATCE against $C$. sakazakii by revealing the changes in membrane potential, intracellular $\mathrm{pH}\left(\mathbf{p H}_{\mathrm{in}}\right)$, bacterial protein content, cellular DNA level, and cell morphology of tested strains.

\section{MATERIALS AND METHODS}

\section{ATCE Material}

The ATCE was prepared by the Key Laboratory of Dairy Science in Northeast Agricultural University (Harbin China). After cleaning, the A. tricolor leaves were dried at $25^{\circ} \mathrm{C}$ in a vacuum desiccator (Parkoo, Guangzhou, China) until there was no significant moisture in the samples, and then ground into powder using a mechanical grinder (Yongkang Boou Machinery Co. Ltd., Zhejiang, China). The powder was then added to $70 \%(\mathrm{vol} / \mathrm{vol})$ ethanol at a ratio of $1: 25(\mathrm{~g} / \mathrm{mL})$ and soaked at $40^{\circ} \mathrm{C}$ for $2 \mathrm{~h}$ for extraction of active ingredients. The extracted solution was filtered, collected, and concentrated into the paste using a reduced pressure rotary evaporator (KNF, Freiburg, Germany). Finally, the paste was dried into powder using a vacuum freeze dryer (Beijing Biocool Co. Ltd., Beijing, China).

\section{Bacteria and Culture Conditions}

A total of 10 C. sakazakii strains were used in this study, including C. sakazakii ATCC 29544 purchased from American Type Culture Collection (ATCC, Manassas, VA) and 9 C. sakazakii strains isolated from PIF (Fei et al., 2017). In all isolates, we determined DIZ, MIC, and MBC values to evaluate the antibacterial activity of ATCE. Cronobacter sakazakii ATCC 29544 was used in experiments to reveal the possible mechanism of action. To culture the strains, $100 \mu \mathrm{L}$ of culture was activated in $10 \mathrm{~mL}$ of tryptic soy broth (TSB) at $37^{\circ} \mathrm{C}$ for $18 \mathrm{~h}$. A loopful of C. sakazakii was streaked onto tryptic soy agar (TSA; Qingdao Haibo Biotechnology Co. Ltd., Qingdao, China) plates and incubated at $37^{\circ} \mathrm{C}$ for $24 \mathrm{~h}$. A typical colony was inoculated into TSB followed by incubation at $37^{\circ} \mathrm{C}$ for $18 \mathrm{~h}$ to obtain the pure cultures of isolates.

\section{Disk Diffusion Assay}

The DIZ of ATCE against 10 C. sakazakii strains were measured using the disk diffusion method reported by Barry (1976). A TSA plate was evenly coated with $100 \mu \mathrm{L}$ of bacterial suspension of $C$. sakazakii (approximately $\left.10^{6} \mathrm{cfu} / \mathrm{mL}\right)$. Filter paper disks $(6 \mathrm{~mm}$ diameter) were soaked with $15 \mu \mathrm{L}$ of ATCE $(80 \mathrm{mg} /$ $\mathrm{mL}$ ); one disk soaked with $15 \mu \mathrm{L}$ of water was used as control. These disks were laid evenly on the TSA plate containing C. sakazakii strains, and incubated at $37^{\circ} \mathrm{C}$ for $24 \mathrm{~h}$. The DIZ of TSB was used as a negative control. In 3 repetitions, the DIZ values of ATCE against C. sakazakii were determined. 


\section{Determination of MIC and MBC}

The MIC of ATCE for all C. sakazakii strains were determined using the agar dilution method according to Fei et al. (2018a). Briefly, ATCE was added to warm TSA that had been autoclaved and cooled to $\sim 50^{\circ} \mathrm{C}$; the final concentrations of ATCE were adjusted to 0, $0.3125,0.625,1.25,2.5,5,10,20$, and $40 \mathrm{mg} / \mathrm{mL}$. The above system was uniformly mixed, and then $500 \mu \mathrm{L}$ of the mixtures were quickly added into sterile 24 -well plates. When the TSA medium with different concentrations of ATCE solidified, $2 \mu \mathrm{L}\left(10^{6} \mathrm{cfu} / \mathrm{mL}\right)$ of each C. sakazakii strain was inoculated to the agar block. The bacterial solution was allowed to dry and then the block was incubated at $37^{\circ} \mathrm{C}$ for $24 \mathrm{~h}$. The MIC was defined as the lowest concentration of ATCE in which $C$. sakazakii strains could not grow visibly. One hundred microliters $\left(10^{6} \mathrm{cfu} / \mathrm{mL}\right)$ of suspensions after treatments with $\geq 1$ MIC of ATCE for 30 min were spread on the TSA, and then cultured at $37^{\circ} \mathrm{C}$ for $24 \mathrm{~h}$. The MBC was defined as the lowest concentration of ATCE that prevented growth of colonies of C. sakazakii.

\section{Growth Curve of C. sakazakii ATCC 29544}

The growth curve of C. sakazakii ATCC 29544 was plotted with reference to a previous report (Shi et al., 2016a). Cronobacter sakazakii was cultured in TSB medium until the optical density at $600 \mathrm{~nm}\left(\mathrm{OD}_{600}\right)$ value of the bacterial solution reached 0.2. Two milliliters of this bacterial solution was added to 96 -well microtiter plates. The ATCE was mixed in the bacterial solution, and adjusted to $0,0.5,1,1.5$, and 2 MIC. For the $C$. sakazakii to grow, all plates were incubated at $37^{\circ} \mathrm{C}$ for $24 \mathrm{~h}$. During this period, cell growth was monitored by measuring $\mathrm{OD}_{600}$ at 2-h intervals using a multimode plate reader (Tecan, Infinite M200 PRO, Männedorf, Switzerland).

\section{Determination of Membrane Potential}

Based on a previous study, the membrane potential of C. sakazakii ATCC 29544 was measured (Fei et al., 2019). Briefly, a suspension of C. sakazakii at $10^{7} \mathrm{cfu} /$ $\mathrm{mL}$ was prepared and seeded in black cell enzyme label plates followed by incubation at $37^{\circ} \mathrm{C}$ for $30 \mathrm{~min}$. Then, $1 \mu \mathrm{mol} / \mathrm{L}$ bis-(1,3-dibutylbarbituric acid) trimethine oxonol [DiBAC4 (3); Beijing Solarbio Sciences and Technology Co. Ltd., Beijing, China] was added to the plates as a membrane potential-sensitive fluorescent probe, and ATCE was added to reach final concentrations of 0,1 , and 2 MIC. The system was incubated at $37^{\circ} \mathrm{C}$ for $30 \mathrm{~min}$ and then fluorescence was measured at excitation and emission wavelengths of 492 and 515 $\mathrm{nm}$, respectively, using a fluorescence microplate reader (Beijing Potenov Technology Co. Ltd., Beijing, China).

\section{Determination of Intracellular $\mathrm{pH}$}

The changes in $\mathrm{pH}_{\text {in }}$ of $C$. sakazakii ATCC 29544 after treatment with ATCE were analyzed based on our previous study (Guo et al., 2020c). Briefly, a suspension of $10^{8} \mathrm{cfu} / \mathrm{mL}$ of C. sakazakii was prepared and incubated at $37^{\circ} \mathrm{C}$ for $30 \mathrm{~min}$; then, $1 \mu M$ carboxyfluorescein diacetate succinimidyl ester (cFDA-SE; Shanghai Yaoyun Biological Technology Co. Ltd., Shanghai, China) was added as a fluorescent probe. The cultures were centrifuged at $11,200 \times g$ for $5 \mathrm{~min}$, the pellet was resuspended in sterilized normal saline, and $10 \mathrm{mM}$ glucose mixed into the suspension. The mixed samples were incubated at $37^{\circ} \mathrm{C}$ for $30 \mathrm{~min}$ and centrifuged at $11,200 \times g$ for $5 \mathrm{~min}$ followed by washing twice. The pellets were resuspended in normal saline $(125 \mu \mathrm{L})$ containing ATCE (1 MIC and $2 \mathrm{MIC}$ ), incubated at $37^{\circ} \mathrm{C}$ for $20 \mathrm{~min}$, and added into black opaque 96 -well plates. Under excitation wavelengths of $440 \mathrm{~nm}$ and emission wavelengths of $490 \mathrm{~nm}$, the fluorescence intensities were measured at $25^{\circ} \mathrm{C}$ using a microplate reader (Tecan, Infinite M200 PRO). The actual fluorescence value of the sample was equal to the measured value minus the value of cell-free control. The $\mathrm{pH}_{\text {in }}$ was defined as the ratio of the actual fluorescence signal at $490 \mathrm{~nm} / 440$ $\mathrm{nm}$.

\section{SDS-PAGE}

We carried out SDS-PAGE based on a previous report (Fei et al., 2019). Briefly, C. sakazakii ATCC 29544 culture $\left(10^{7} \mathrm{cfu} / \mathrm{mL}\right)$ was prepared and treated with $1 \mathrm{MIC}$ and $2 \mathrm{MIC}$ of ATCE at $37^{\circ} \mathrm{C}$ for $3,6,9$, and 12 h. Untreated C. sakazakii was used as the control. All samples were centrifuged at $8,000 \times g$ for 10 min at $4^{\circ} \mathrm{C}$ to obtain the supernatant. The supernatant $(15$ $\mu \mathrm{L})$ was mixed with SDS-PAGE loading buffer $(5 \mu \mathrm{L})$ followed by heat treatment at $95^{\circ} \mathrm{C}$ for $10 \mathrm{~min}$. Twenty microliters of sample was analyzed by SDS-PAGE using a $5 \%$ stacking gel and a $15 \%$ separating gel. The gels were dyed with Coomassie Brilliant Blue R-250 (Shanghai Regal Biology Technology Co. Ltd., Shanghai, China), and scanned for imaging using an E-Gel imager (Thermo Fisher, Waltham, MA).

\section{Agarose Gel Electrophoresis for DNA Fragmentation}

The effect of ATCE on the genomic DNA of C. sakazakii ATCC 29544 was analyzed as previously described (Guo et al., 2019). Briefly, after treatments with 0 (control), 1, and $2 \mathrm{MIC}$ of $\mathrm{ATCE}$ at $37^{\circ} \mathrm{C}$ for 2,4 , and 10 
h, the genomic DNA of C. sakazakii $\left(10^{8} \mathrm{cfu} / \mathrm{mL}\right)$ was extracted using a bacterial genomic DNA extraction kit (Tiangen Biotech Co. Ltd., Beijing, China), and electrophoresed using $1.5 \%$ agarose gel at $100 \mathrm{~V}$ for $30 \mathrm{~min}$. Finally, the gel was stained with ethidium bromide (10 $\mathrm{mg} / \mathrm{mL}$ ) for $15 \mathrm{~min}$, and imaged using a gel imaging system (Bio-Rad Laboratories, Hercules, CA).

\section{Transmission Electron Microscopy Analysis}

The cell morphology of C. sakazakii ATCC 29544 was observed using transmission electron microscope (TEM) as previously reported (Fei et al., 2018a). Briefly, C. sakazakii cultures were treated with 1 and 2 MIC at $37^{\circ} \mathrm{C}$ for $4 \mathrm{~h}$, and untreated culture was used as control. The above mixtures were centrifuged at 8,000 $\times g$ for 5 min at $4^{\circ} \mathrm{C}$ to obtain cells from the working culture, which were fixed in $0.1 M$ sodium phosphate buffer containing $2.5 \%$ glutaraldehyde for $12 \mathrm{~h}$ followed by washing twice with sterilized normal saline. To further fix the cells, the pellets were treated with $1 \%$ osmium tetraoxide at $25^{\circ} \mathrm{C}$ for $6 \mathrm{~h}$ and washed 3 times with normal saline. The cells were dehydrated in a graded series of ethanol (50, 70, 90, and 100\%) for 10 min, and embedded in Epon Lx-112 (Ladd Research, Williston, VT). Finally, the cells were double-stained with uranyl acetate and lead citrate and observed using TEM (Hitachi, Tokyo, Japan).

\section{Activity of ATCE Against C. Sakazakii in Biofilm on Stainless Steel}

The activity of ATCE against C. sakazakii in biofilm on stainless steel was analyzed as previously described (Guo et al., 2020a), with minor modifications. Briefly, sterile American Iron and Steel Institute (AISI)-304 stainless steel coupons $(50 \times 20 \mathrm{~mm})$ were added to a $50-\mathrm{mL}$ tube followed by the addition of $30 \mathrm{~mL}$ of bacterial suspension $\left(10^{7} \mathrm{cfu} / \mathrm{mL}\right)$. The coupons were cultured at $4^{\circ} \mathrm{C}$ for $24 \mathrm{~h}$ and washed twice with $300 \mathrm{~mL}$ of sterile distilled water (SDW) for $10 \mathrm{~s}$. To further simulate the presence of $C$. sakazakii on equipment surfaces in a PIF plant, the coupons were incubated in $30 \mathrm{~mL}$ of $\mathrm{TSB} 25^{\circ} \mathrm{C}$ for $24 \mathrm{~h}$ to form more biofilms, followed by washing twice with $300 \mathrm{~mL}$ of SDW for 10 s. These prepared coupons were incubated in $30 \mathrm{~mL}$ of ATCE solution at concentrations of 0,1 , and 2 MIC for $0,10,20$, and $30 \mathrm{~min}$ at $25^{\circ} \mathrm{C}$, respectively. At each sampling point, the coupons were washed twice with $300 \mathrm{~mL}$ of SDW for $10 \mathrm{~s}$ and transferred to $50-\mathrm{mL}$ tubes containing $30 \mathrm{~mL}$ of sterile PBS and $3 \mathrm{~g}$ of glass beads (300-600 $\mu \mathrm{m}$, Yongqing Huayang Glass Products Co Ltd., Yongqing, China). After 5 min of vortexing, the number of bacteria in PBS was determined by the plate count method.

\section{Statistical Analysis}

Each experiment involving data analysis was carried out in triplicate. All experimental data are presented as mean values \pm standard deviations (SD). Differences between treatments were analyzed by ANOVA using the SPSS 20.0 software (IBM Corp., Armonk, NY). P $<0.05$ was considered to indicate a significant difference.

\section{RESULTS}

\section{DIZ, MIC, and MBC of ATCE on C. sakazakii Strains}

The DIZ, MIC, and MBC of ATCE against the 10 C. sakazakii strains were determined and results are shown in Table 1 . The negative control did not produce an inhibition zone, whereas the mean DIZ of ATCE against C. sakazakii strains ranged from $14.35 \pm 0.67$ to $14.84 \pm 0.67 \mathrm{~mm}$. We observed no difference $(P>$ $0.05)$ in DIZ of ATCE against all tested strains. The MIC of ATCE against all C. sakazakii strains was 20 $\mathrm{mg} / \mathrm{mL}$, and the MBC of ATCE against all strains was $40 \mathrm{mg} / \mathrm{mL}$.

\section{Growth Curve}

As shown in Figure 1, the effects of ATCE at 0.5 to 2 MIC on the growth of C. sakazakii ATCC 29544 were analyzed. After treatments with different concentrations of ATCE, growth of the C. sakazakii strain was significantly inhibited. As the concentration of ATCE

Table 1. Antibacterial activity ${ }^{1}$ of Amaranthus tricolor crude extract against 10 Cronobacter sakazakii strains isolated from powdered infant formula (PIF)

\begin{tabular}{lccc}
\hline Strain $^{2}$ & $\begin{array}{c}\text { DIZ } \\
(\mathrm{mm} ; \text { mean } \pm \mathrm{SD})\end{array}$ & $\begin{array}{c}\text { MIC } \\
(\mathrm{mg} / \mathrm{mL})\end{array}$ & $\begin{array}{c}\mathrm{MBC} \\
(\mathrm{mg} / \mathrm{mL})\end{array}$ \\
\hline ATCC 29544 & $14.50 \pm 0.80^{\mathrm{a}}$ & 20 & 40 \\
FP1 & $14.35 \pm 0.67^{\mathrm{a}}$ & 20 & 40 \\
FP5 & $14.47 \pm 0.38^{\mathrm{a}}$ & 20 & 40 \\
FP7 & $14.27 \pm 0.49^{\mathrm{a}}$ & 20 & 40 \\
CBM5 & $14.49 \pm 0.65^{\mathrm{a}}$ & 20 & 40 \\
CBM9 & $14.69 \pm 0.59^{\mathrm{a}}$ & 20 & 40 \\
ML10 & $14.84 \pm 0.67^{\mathrm{a}}$ & 20 & 40 \\
ML12 & $14.56 \pm 0.62^{\mathrm{a}}$ & 20 & 40 \\
AD6 & $14.59 \pm 0.70^{\mathrm{a}}$ & 20 & 40 \\
AD9 & $14.73 \pm 0.58^{\mathrm{a}}$ & 20 & 40 \\
\hline
\end{tabular}

${ }^{\mathrm{a}}$ Values within a column with the same letters do not differ significantly $(P<0.05)$.

${ }^{1} \mathrm{DIZ}=$ diameter of inhibition zone; $\mathrm{MBC}=$ minimum bactericidal concentration.

${ }^{2}$ Strains were isolated from PIF except for ATCC 29544, which was from the American Type Culture Collection (Manassas, VA). 


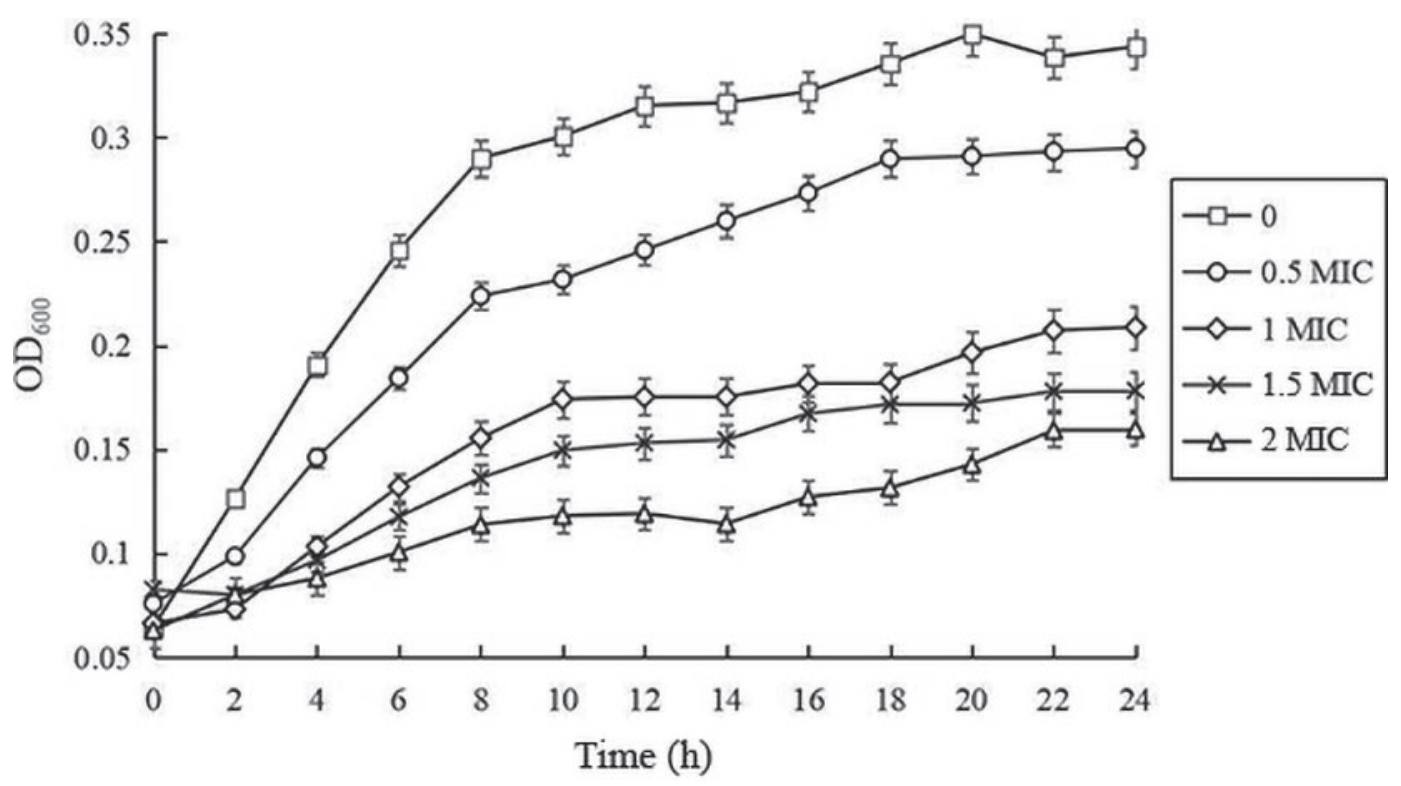

Figure 1. Effects of different concentrations of Amaranthus tricolor crude extract on the growth curve (measured as optical density at 600 $\left.\mathrm{nm}, \mathrm{OD}_{600}\right)$ of Cronobacter sakazakii ATCC 29544. Bars represent the SD $(\mathrm{n}=3)$.

increased, the growth of $C$. sakazakii slowed, but did not stop completely. When the concentration of ATCE was $\geq 1 \mathrm{MIC}$, the logarithmic phase of C. sakazakii ended and was replaced by slow proliferation.

\section{Changes in Membrane Potential}

The changes in membrane potential of $C$. sakazakii ATCC 29544 after treatments with ATCE are shown in Figure 2. Compared with untreated cells, C. sakazakii treated with ATCE at $1 \mathrm{MIC}$ and 2 MIC had a significant increase in the amount of fluorescence $(P<0.05)$, indicating that ATCE treatment led to the depolarization of C. sakazakii cells. In addition, no significant change in amount of fluorescence was found between 1 MIC and 2 MIC, which may be because the depolarization of membrane potential of the tested strains reached a maximal concentration between 1 MIC and 2 MIC.

\section{Changes in $\mathrm{pH}_{\text {in }}$}

We observed good linearity between fluorescence intensity ratio $(490 \mathrm{~nm} / 440 \mathrm{~nm})$ and $\mathrm{pH}_{\mathrm{in}}(\mathrm{y}=-1.0689 \mathrm{x}$ $\left.+12.847 ; \mathrm{R}^{2}=0.9973\right)$. The $\mathrm{pH}_{\text {in }}$ value of $C$. sakazakii ATCC 29544 after treatment with 1 and 2 MIC of ATCE decreased significantly $(P<0.05$; Figure 3$)$. Further, the $\mathrm{pH}_{\mathrm{in}}$ of untreated C. sakazakii was $7.49 \pm$ 0.71 , which decreased to $4.56 \pm 0.98$ and $3.31 \pm 0.81$, respectively, after treatment with $1 \mathrm{MIC}$ and $2 \mathrm{MIC}$ of ATCE at $37^{\circ} \mathrm{C}$ for $20 \mathrm{~min}$. No difference $(P>0.05)$ was found in $\mathrm{pH}_{\text {in }}$ value between $C$. sakazakii cells treated with $1 \mathrm{MIC}$ and $2 \mathrm{MIC}$ of ATCE.

\section{SDS-PAGE Analysis}

The SDS-PAGE images (Figure 4) showed significant changes in bacterial protein levels of $C$. sakazakii ATCC 29544 within $12 \mathrm{~h}$ of ATCE treatment at $1 \mathrm{MIC}$ and 2 MIC. As shown in Figure 4A, the protein bands of $C$. sakazakii treated by $1 \mathrm{MIC}$ of ATCE became fainter as treatment time increased. Figure 4B shows that the protein bands of $C$. sakazakii treated at 2 MIC were weaker compared with those of control group. Furthermore, protein bands of C. sakazakii disappeared after treatment with $2 \mathrm{MIC}$ of ATCE for $12 \mathrm{~h}$.

\section{DNA Cleavage Analysis}

The effects of ATCE on genomic DNA levels of $C$. sakazakii ATCC 29544 are shown in Figure 5. Compared with untreated C. sakazakii, the DNA bands of strains after exposure to ATCE became fainter with increasing treatment time and concentration. The bands disappeared completely after $10 \mathrm{~h}$ of treatment with 2 MIC ATCE.

\section{TEM Observation}

Differences in cell morphology of C. sakazakii ATCC 29544 with and without ATCE treatment were ob- 


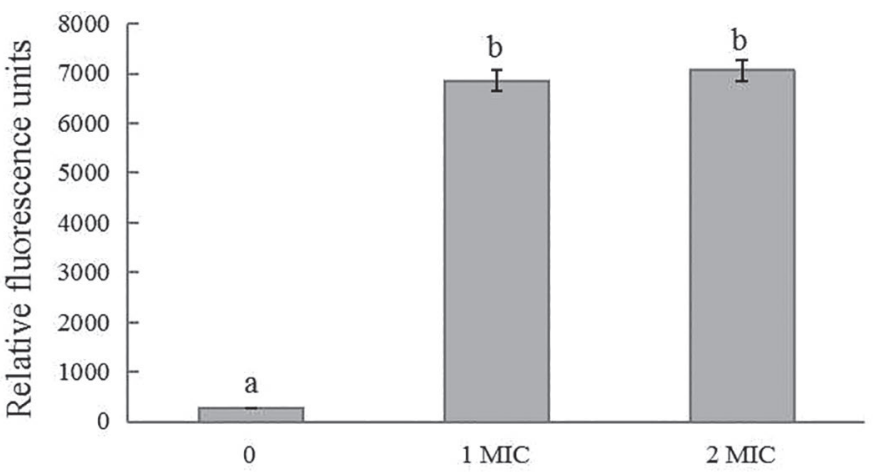

The concentration of ATCE

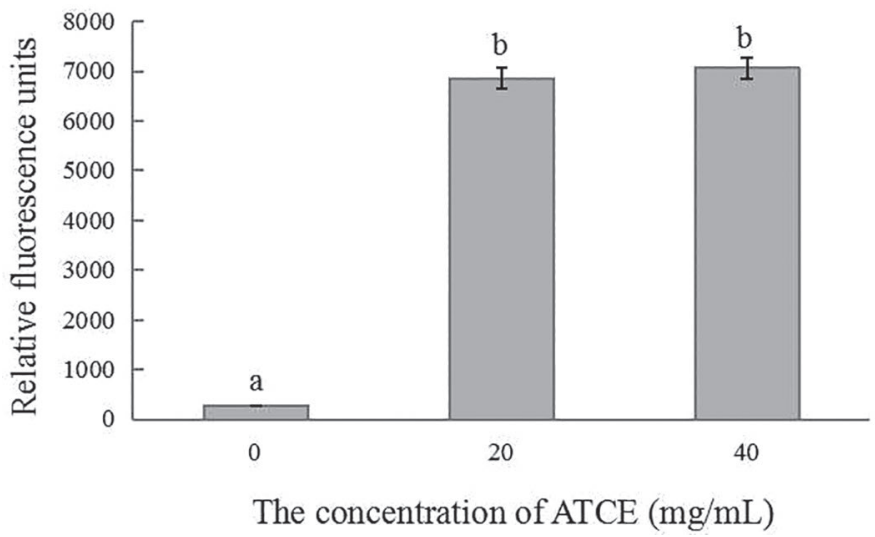

Figure 2. Effects of Amaranthus tricolor crude extract (ATCE) concentration on the membrane potential (in relative fluorescence units) of Cronobacter sakazakii ATCC 29544. The mean values of independent triplicate experiments were analyzed. Bars represent the $\mathrm{SD}(\mathrm{n}=3)$. Different letters $(\mathrm{a}, \mathrm{b})$ denote significant differences $(P$ $<0.05)$.

served, as shown in Figure 6. Compared with untreated cells (Figure 6A), C. sakazakii cells after treatment with ATCE at 1 MIC (Figure 6B) and 2 MIC (Figure 6C) showed severe surface depression, cytoplasmic leakage, and deformation; the damage to cell morphology became more severe with increasing ATCE concentration.

\section{Effect of ATCE Against C. sakazakii in Biofilm on Stainless Steel}

Figure 7 shows the number of viable bacteria after treatment with 0,1 , and 2 MIC of ATCE for 0, 10, 20 , and $30 \mathrm{~min}$ at $25^{\circ} \mathrm{C}$. Compared with the control group (0 MIC), counts of C. sakazakii strains in biofilm on stainless steel were significantly reduced after treatments with ATCE $(P<0.05)$. When the concentration of ATCE was $1 \mathrm{MIC}$, the time to inactivate $\sim 6.5 \mathrm{log}$ $\mathrm{cfu} / \mathrm{mL}$ of C. sakazakii was $30 \mathrm{~min}$; when the concentration was $2 \mathrm{MIC}$, the inactivation time was $20 \mathrm{~min}$.

\section{DISCUSSION}

Natural extracts have been extensively studied as potential preservatives and disinfectants based on their antioxidant activity (Fei et al., 2018a; Wu et al., 2019; Xiang et al., 2019). In previous studies, the DIZ values of standard vincristine sulfate, chloroform, $n$-hexane, and ethyl acetate extracts of $A$. spinosus against 11 pathogens excluding C. sakazakii were reported to be 8 to $15 \mathrm{~mm}$ (Bulbul et al., 2011), whereas the MIC of A. spinosus extracts against Salmonella typhi was 129 $\mathrm{mg} / \mathrm{mL}$, and those of A. hybridus and A. caudatus extracts against 8 tested organisms were 200 to $755 \mathrm{mg} /$ $\mathrm{mL}$ and 162.2 to $665 \mathrm{mg} / \mathrm{mL}$, respectively (Maiyo et al., 2010). In this study, ATCE was prepared and used to inhibit C. sakazakii isolated from PIF. The MIC of ATCE against C. sakazakii strains was $20 \mathrm{mg} / \mathrm{mL}$, a value higher than that of some other pure natural products, such as eugenol $(\mathrm{MIC}=1.0 \mathrm{mg} / \mathrm{mL})$, lipoic acid $(\mathrm{MIC}=2.5-5 \mathrm{mg} / \mathrm{mL})$, and syringic acid ( $\mathrm{MIC}=$ $5.0 \mathrm{mg} / \mathrm{mL}$ ) (Bajpai et al., 2013; Shi et al., 2016b,c),
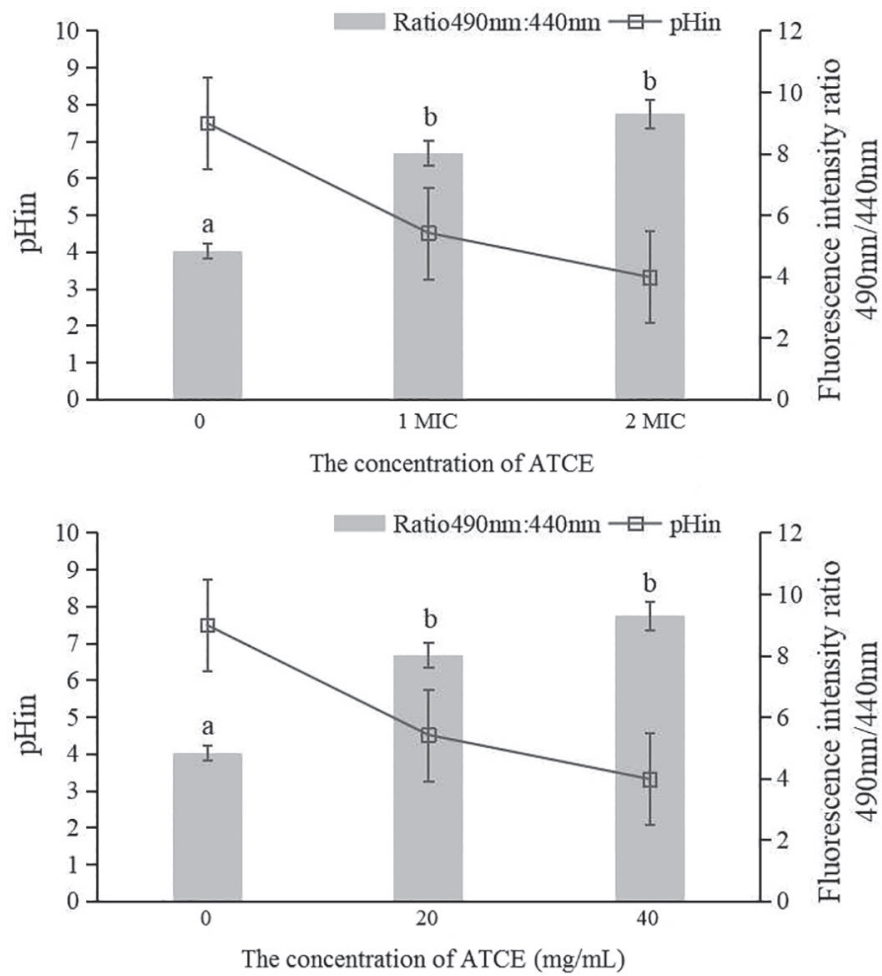

Figure 3. Changes in intracellular $\mathrm{pH}$, which was calculated by the ratio of fluorescence emission intensities at 490 and $440 \mathrm{~nm}(-\square-$ , $\left.\mathrm{pH}_{\mathrm{in}}\right)$ of Cronobacter sakazakii ATCC 29544 after treatment with Amaranthus tricolor crude extract (ATCE). Values represent the means of independent triplicate measurements. Bars represent the SD $(\mathrm{n}=3)$. Different letters $(\mathrm{a}, \mathrm{b})$ denote significant differences $(P<$ $0.05)$. 
which indicated that further concentrations of ATCE should be evaluated to achieve a better bacteriostatic effect. Similarly, the average MIC of polyphenol-rich pomegranate peel extract $(\mathrm{pH}=6.0)$ against $C$. sakazakii was $20 \mathrm{mg} / \mathrm{mL}$, according to the report of Yemis et al. (2019), who deemed that a MIC of $20 \mathrm{mg} / \mathrm{mL}$ was acceptable for the crude extract, and that a concentration process be performed before using the extract as a disinfectant.

Membrane potential is closely related to the normal physiological activities of bacteria and can help bacteria resist the absorption of antibiotics and bactericidal action (Guo et al., 2019). Without external interference, the membrane potential of bacteria is in a resting state; however, once the membrane potential is changed, normal growth of bacteria is inhibited (Bot and Prodan, 2009). Previous studies have shown that the most common changes in membrane potential are cell membrane depolarization and hyperpolarization. Cell membrane depolarization is associated with opening of the $\mathrm{Na}^{+}$channels, which allows $\mathrm{Na}^{+}$to migrate into the cell, reducing the intracellular negative charge. Cell membrane hyperpolarization is related to the increase in intracellular negative charge caused by leakage of $\mathrm{K}^{+}$ions out of the cell (Gries et al., 2013; Guo et al., 2020a). In this study, ATCE caused cell membrane depolarization of C. sakazakii; similarly, the antibacterial activity of OOPE and lipoic acid was associated with cell membrane depolarization (Shi et al., 2016b;
Fei et al., 2018a). Treatment of C. sakazakii cells with citral, syringic acid, and coenzyme $\mathrm{Q}_{0}$ resulted in cell membrane hyperpolarization (Shi et al., 2016a,c; Guo et al., 2020a).

Homeostasis of $\mathrm{pH}_{\text {in }}$ is an important environmental condition for enzymatic biochemical reactions, DNA translation, and protein synthesis of bacterial cells (Bracey, et al., 1998). When cell membrane integrity is compromised, the cell cannot maintain $\mathrm{pH}_{\text {in }}$ through ion channels; therefore, changes in $\mathrm{pH}_{\mathrm{in}}$ are a useful indicator of whether bacterial cells are damaged (Fitzgerald, et al., 2004). In the current study, the $\mathrm{pH}_{\text {in }}$ of $C$. sakazakii decreased significantly after treatment with ATCE, indicating that cellular integrity of the tested bacteria was severely damaged, leading to inhibition of bacterial growth. Similarly, a decrease in $\mathrm{pH}_{\text {in }}$ was an important bacteriostatic factor during the antibacterial process of oregano essential oil, thymol, and carvacrol against Staphylococcus aureus, and of lipoic acid against C. sakazakii strains (Lambert et al., 2001; Shi et al., 2016b).

Previous studies have shown that natural products can inhibit bacterial protein synthesis, accelerate protein breakdown, and improve membrane permeability, resulting in a significant reduction in bacterial protein content (Di Pasqua et al., 2010; Guo et al., 2020b). Our findings showed that C. sakazakii exposed to ATCE had lower levels of bacterial proteins than untreated cells. Similarly, Chen et al. (2017) found that after treat-

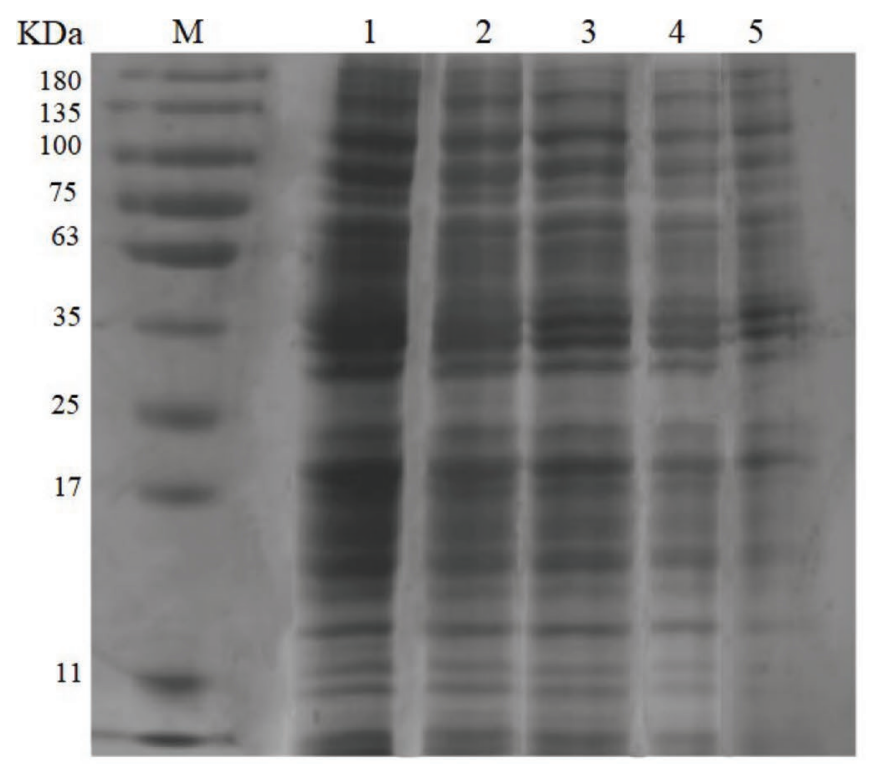

(A)

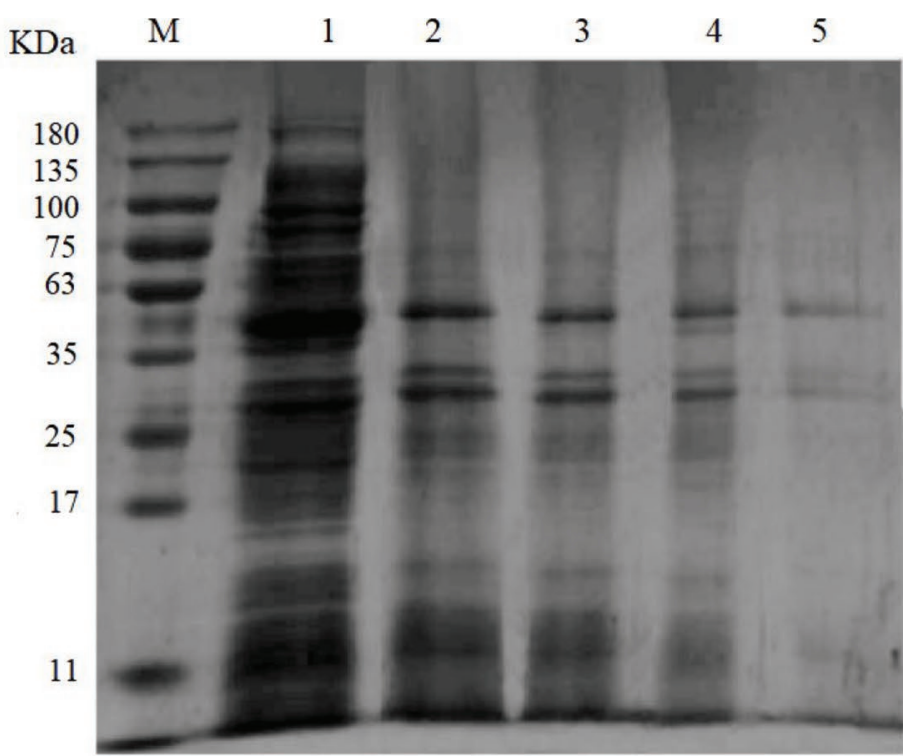

(B)

Figure 4. Sodium dodecyl sulfate-PAGE analysis of Cronobacter sakazakii ATCC 29544 proteins treated with concentrations (A) 1 MIC and (B) 2 MIC of Amaranthus tricolor crude extract (ATCE). Lane M = marker; lane 1: control; lanes 2, 3, 4, 5: treatment with 1 MIC or 2 MIC of ATCE for $3,6,9,12 \mathrm{~h}$, respectively. 


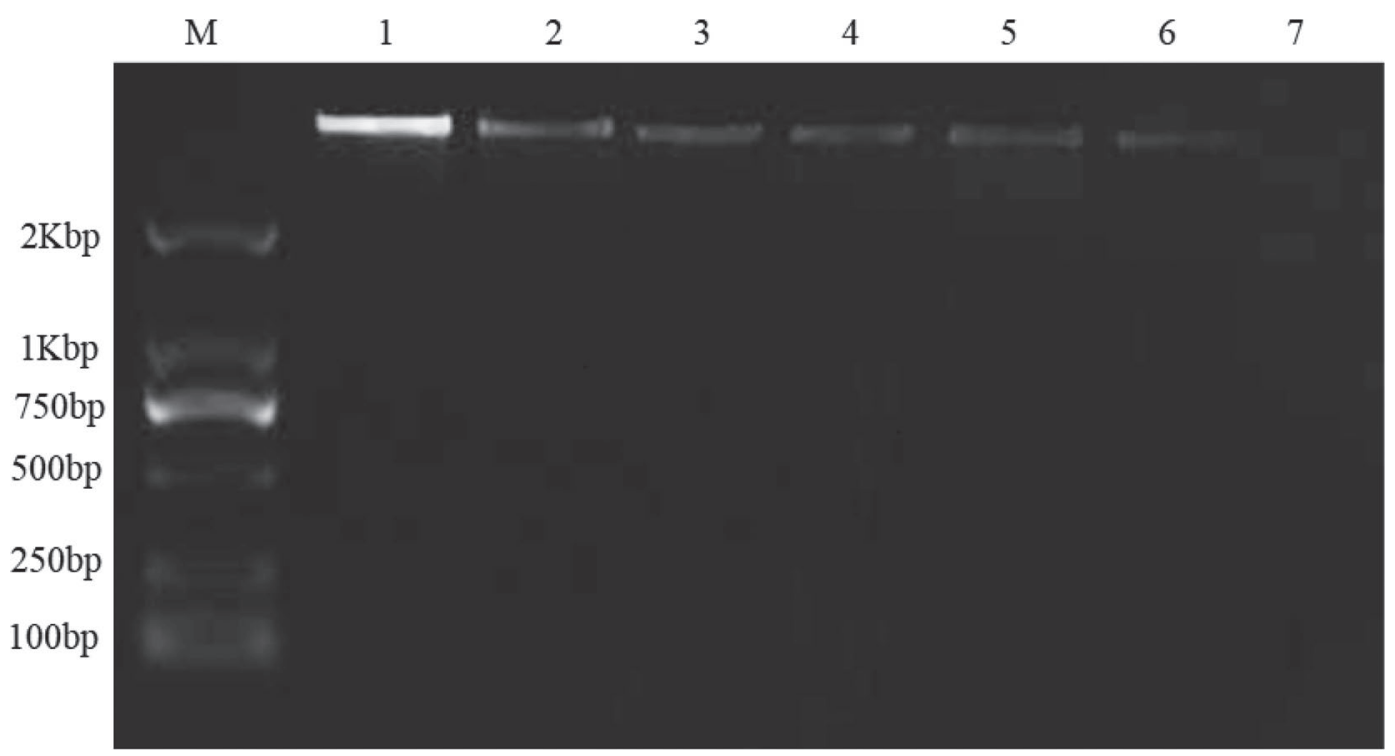

Figure 5. Agarose gel electrophoresis analysis of the DNA of Cronobacter sakazakii ATCC 29544 treated by 1 MIC and 2 MIC of Amaranthus tricolor crude extract (ATCE). Lane $1=$ control; lanes 2, 3, 4 = treatment with 1 MIC of ATCE for 2, 4, 10 h, respectively; lanes 5, 6, 7: treatment with $2 \mathrm{MIC}$ of ATCE for 2, 4, $10 \mathrm{~h}$, respectively.

ment with sugar beet molasses polyphenols, the protein content of food-borne pathogens was significantly reduced, including Staph. aureus, Listeria monocytogenes, Escherichia coli, and Salmonella Typhimurium. Fei et al. (2018a) reported that the inhibitory effect of OOPE on C. sakazakii was related to the decrease of bacterial protein level.

The DNA content of bacterial cells is closely related to their growth and proliferation; once synthesis of DNA is blocked or lost, growth of bacteria can be inhibited (Cui et al., 2018). In our study, DNA bands of C. sakazakii on agarose gel were fainter and eventually disappeared after treatment with ATCE, similar to the results of Guo et al. (2020c), who revealed a change in bacterial DNA in the antimicrobial action of ATCE against Staph. aureus. Wang et al. (2017) reported that the antibacterial action of clove oil-containing phenols against L. monocytogenes was associated with DNA fragmentation and reduction. A previous report (Guo et al., 2019) listed 2 ways in which polyphenols reduced the DNA content of the pathogen: (1) cell morphology of tested bacteria was destroyed, leading to increased cell membrane permeability and DNA leakage; and (2) the secondary structure and morphology of DNA were altered by the association of polyphenols with the minor grooves in DNA.
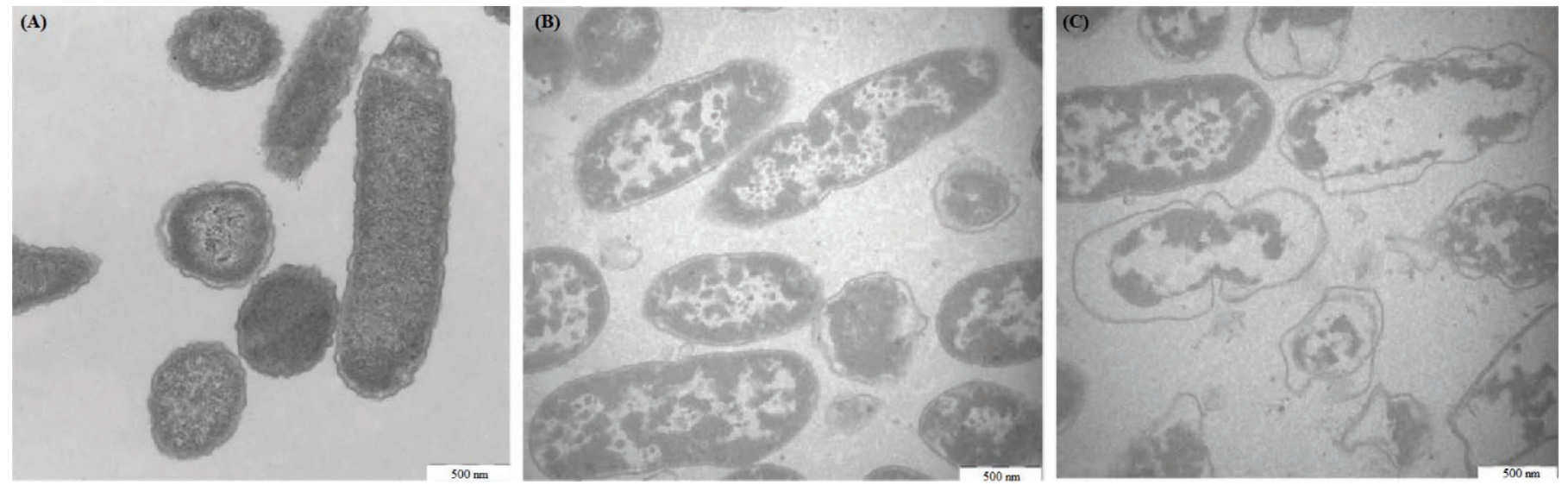

Figure 6. Cell morphology of Cronobacter sakazakii ATCC $29544(40,000 \times)$ under the transmission electron microscopy. (A) Untreated for $4 \mathrm{~h},(\mathrm{~B})$ treated with $1 \mathrm{MIC}$ of Amaranthus tricolor crude extract (ATCE) for $4 \mathrm{~h},(\mathrm{C})$ treated with $2 \mathrm{MIC}$ of ATCE for $4 \mathrm{~h}$. 


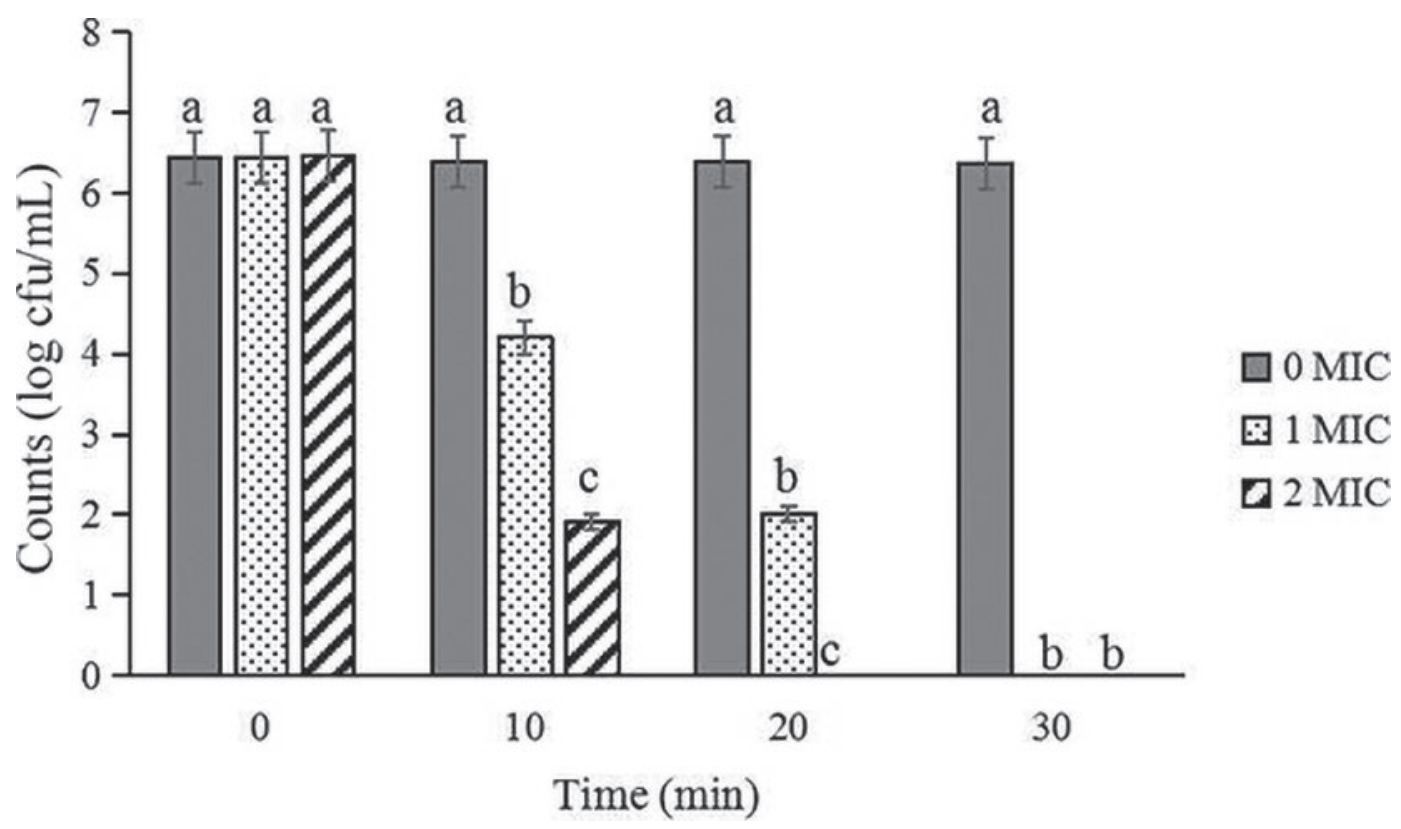

Figure 7. Inactivation effect of Amaranthus tricolor crude extract (ATCE) against Cronobacter sakazakii in biofilm on a stainless steel tube at $25^{\circ} \mathrm{C}$. Bars represent the SD $(\mathrm{n}=3)$. Different letters $(\mathrm{a}-\mathrm{c})$ denote significant differences $(P<0.05)$ for different MIC within a timepoint.

The TEM results showed that ATCE caused cytoplasmic leakage and cell morphological damage of $C$. sakazakii; similar results were found for the action of OOPE and tea polyphenols against C. sakazakii (Li et al., 2016; Fei et al., 2018a), which indicated that the effect of these natural products on pathogens is irreversible. Natural products with different components have different effects on bacterial cell morphology. Compared with the leakage of cell fluid, pores and bubbles appeared on the cell surface, indicating that the corresponding natural products had bacteriostatic rather than bactericidal effects on the tested bacteria. The bacteriostatic effect is reversible, and the treated bacteria can be resurrected (Joshi et al., 2014). Xu et al. (2017) found that Staph. aureus cells became larger and rougher after treatment with punicalagin. Shi et al. (2016c) reported that compared with untreated cells, the cell surface of $C$. sakazakii exposed to syringic acid collapsed and shrank. In addition, coenzyme $Q_{0}$ was shown to deform the rod shape of $C$. sakazakii but not cause cell disintegration or appearance of visible pores (Guo et al., 2020a).

In our study, ATCE was used to inactivate C. sakazakii on stainless steel. In the production of PIF, once production equipment becomes contaminated, C. sakazakii is very difficult to eliminate because of its adhesion to surfaces and strong resistance to desiccation; some capsulated C. sakazakii strains have been revived after 2.5 years in a dry environment (Barron and Forsythe, 2007;
Henry and Fouladkhah, 2019). Therefore, we simulated the adhesion of $C$. sakazakii to the surface of stainless steel, resulting in approximately $6.5 \log \mathrm{cfu} / \mathrm{mL}$ of $C$. sakazakii in biofilms on stainless steel. After treatment with $1 \mathrm{MIC}$ or $2 \mathrm{MIC}$ of $\mathrm{ATCE}$ at $25^{\circ} \mathrm{C}$, C. sakazakii on the stainless steel was completely inactivated. In contrast, under the same conditions, the inhibitory effect of coenzyme $\mathrm{Q}_{0}$ on $C$. sakazakii was not significant (Guo et al., 2020a), which may be because coenzyme $\mathrm{Q}_{0}$ does not result in serious leakage of cell fluid of $C$. sakazakii. In addition, to reduce experimental error, the tested strains were immersed in ATCE solution rather than sprayed with ATCE. However, considering that $C$. sakazakii would not reach $6.5 \mathrm{log} \mathrm{cfu} / \mathrm{mL}$ in the realworld environment and we could increase the concentration of ATCE or develop a compound disinfectant, ATCE should be used as a spray-type disinfectant.

\section{CONCLUSIONS}

We showed that ATCE could inhibit C. sakazakii isolated from powdered infant formula, and as a crude extract, ATCE showed moderate antibacterial activity against C. sakazakii. The possible mechanism of action of ATCE involved depolarization of the cell membrane, a decrease in $\mathrm{pH}_{\mathrm{in}}$, significant reductions in levels of bacterial proteins and genomic DNA, cytoplasmic leakage, and deformation. Our findings indicate that ATCE could be used as a spray-type disinfectant to inhibit 
C. sakazakii strains in PIF production environments or on packaging materials. However, further study on the dosage of ATCE as the disinfectant is still necessary.

\section{ACKNOWLEDGMENTS}

This study was supported by the Doctor Scientific Research Start-up Fund of Henan University of Science and Technology (13480066, Luoyang, China), Special Funding of Guiyang Science and Technology Bureau and Guiyang University [GYU-KYZ(2018)01-14, Guiyang, China], and National Natural Science Foundation of China (31601450, Beijing, China). The authors have stated no conflicts of interest.

\section{REFERENCES}

Al-Nabulsi, A. A., T. M. Osaili, M. A. Al-Holy, R. R. Shaker, M. M. Ayyash, A. N. Olaimat, and R. A. Holley. 2009. Influence of desiccation on the sensitivity of Cronobacter spp. to lactoferrin or nisin in broth and powdered infant formula. Int. J. Food Microbiol. 136:221-226. https://doi.org/10.1016/j.ijfoodmicro.2009.08.008.

Bajpai, V. K., A. Sharma, and K.-H. Baek. 2013. Antibacterial mode of action of Cudrania tricuspidata fruit essential oil, affecting membrane permeability and surface characteristics of food-borne pathogens. Food Control 32:582-590. https://doi.org/10.1016/j foodcont.2013.01.032.

Barron, J. C., and S. J. Forsythe. 2007. Dry stress and survival time of Enterobacter sakazakii and other Enterobacteriaceae in dehydrated powdered infant formula. J. Food Prot. 70:2111-2117. https://doi .org/10.4315/0362-028X-70.9.2111.

Barry, A. L. 1976. The Antimicrobic Susceptibility Test: Principles and Practices. Lea \& Febiger, New York, NY.

Bot, C., and C. Prodan. 2009. Probing the membrane potential of living cells by dielectric spectroscopy. Eur Biophys. J. 38:1049-1059. https://doi.org/10.1007/s00249-009-0507-0.

Bracey, D., C. D. Holyoak, G. Nebe-Von Caron, and P. J. Coote. 1998. Determination of the intracellular $\mathrm{pH}(\mathrm{pHi})$ of growing cells of Saccharomyces cerevisiae: The effect of reduced-expression of the membrane $\mathrm{H}^{+}$-ATPase. J. Microbiol. Methods 31:113-125. https:/ /doi.org/10.1016/S0167-7012(97)00095-X.

Brandl, H., C. Fricker-Feer, D. Ziegler, J. Mandal, R. Stephan, and A. Lehner. 2014. Distribution and identification of culturable airborne microorganisms in a Swiss milk processing facility. J. Dairy Sci. 97:240-246. https://doi.org/10.3168/jds.2013-7028.

Bulbul, I. J., L. Nahar, F. A. Ripa, and O. Haque. 2011. Antibacterial, cytotoxic and antioxidant activity of chloroform, n-hexane and ethyl acetate extract of plant Amaranthus spinosus. Int. J. Pharm. Tech. Res. 3:1675-1680.

Caubilla-Barron, J., E. Hurrell, S. Townsend, P. Cheetham, C. LocCarrillo, O. Fayet, M.-F. Prere, and S. J. Forsythe. 2007. Genotypic and phenotypic analysis of Enterobacter sakazakii strains from an outbreak resulting in fatalities in a neonatal intensive care unit in France. J. Clin. Microbiol. 45:3979-3985. https://doi.org/ 10.1128/JCM.01075-07.

Chen, M. S., Z. G. Zhao, H. C. Meng, and S. J. Yu. 2017. Antibiotic activity and mechanisms of sugar beet (Beta vulgaris) molasses polyphenols against selected food-borne pathogens. Lebensm. Wiss. Technol. 82:354-360. https://doi.org/10.1016/j.lwt.2017.04 .063 .

Cui, H. Y., C. H. Zhang, C. Z. Li, and L. Lin. 2018. Antimicrobial mechanism of clove oil on Listeria monocytogenes. Food Control 94:140-146. https://doi.org/10.1016/j.foodcont.2018.07.007.

Fei, P., M. A. Ali, S. Gong, Q. Sun, X. Bi, S. Liu, and L. Guo. 2018a. Antimicrobial activity and mechanism of action of olive oil poly- phenols extract against Cronobacter sakazakii. Food Control 94:289-294. https://doi.org/10.1016/j.foodcont.2018.07.022.

Fei, P., Y. Jiang, S. Gong, R. Li, Y. Jiang, X. Yuan, Z. Wang, H. Kang, and M. A. Ali. 2018b. Occurrence, genotyping, and antibiotic susceptibility of Cronobacter spp. in drinking water and food samples from Northeast China. J. Food Prot. 81:456-460. https:// doi.org/10.4315/0362-028X.JFP-17-326.

Fei, P., C. Man, B. Lou, S. J. Forsythe, Y. Chai, R. Li, J. Niu, and Y. Jiang. 2015. Genotyping and source tracking of Cronobacter sakazakii and C. malonaticus isolates from powdered infant formula and an infant formula production factory in China. Appl. Environ. Microbiol. 81:5430-5439. https://doi.org/10.1128/AEM.01390-15.

Fei, P., Y. Xu, S. Zhao, S. Gong, and L. Guo. 2019. Olive oil polyphenol extract inhibits vegetative cells of Bacillus cereus isolated from raw milk. J. Dairy Sci. 102:3894-3902. https://doi.org/10.3168/ jds.2018-15184.

Fei, P., Y. Jiang, Y. Jiang, X. Yuan, T. Yang, J. Chen, Z. Wang, H. Kang, and S. J. Forsythe. 2017. Prevalence, molecular characterization, and antibiotic susceptibility of Cronobacter sakazakii isolates from powdered infant formula collected from Chinese retail markets. Front. Microbiol. 8:2026. https://doi.org/10.3389/fmicb .2017 .02026 .

Fitzgerald, D. J., M. Stratford, M. J. Gasson, J. Ueckert, A. Bos, and A. Narbad. 2004. Mode of antimicrobial action of vanillin against Escherichia coli, Lactobacillus plantarum and Listeria innocua. J. Appl. Microbiol. 97:104-113. https://doi.org/10.1111/j.1365-2672 .2004.02275.x.

Gries, C. M., J. L. Bose, A. S. Nuxoll, P. D. Fey, and K. W. Bayles. 2013. The Ktr potassium transport system in Staphylococcus aureus and its role in cell physiology, antimicrobial resistance and pathogenesis. Mol. Microbiol. 89:760-773. https://doi.org/10 $.1111 / \mathrm{mmi} .12312$.

Guo, D., S. Wang, J. Li, F. Bai, Y. Yang, Y. Xu, S. Liang, X. Xia, X. Wang, and C. Shi. 2020a. The antimicrobial activity of coenzyme $\mathrm{Q}_{0}$ against planktonic and biofilm forms of Cronobacter sakazakii. Food Microbiol. 86:103337. https://doi.org/10.1016/j.fm.2019 .103337 .

Guo, L., Q. Sun, S. Gong, X. Bi, W. Jiang, W. Xue, and P. Fei. 2019. Antimicrobial activity and action approach of the olive oil polyphenol extract against Listeria monocytogenes. Front. Microbiol. 10:1586

Guo, L., S. Gong, Y. Wang, Q. Sun, K. Duo, and P. Fei. 2020b. Antibacterial activity of olive oil polyphenols extract against Salmonella Typhimurium and Staphylococcus aureus: Possible mechanisms. Foodborne Pathog. Dis. 17:396-403. https://doi.org/10.1089/fpd 2019.2713.

Guo, L., Y. Wang, X. Bi, K. Duo, Q. Sun, X. Yun, Y. Zhang, P. Fei, and J. Han. 2020c. Antimicrobial activity and mechanism of action of the Amaranthus tricolor crude extract against Staphylococcus aureus and potential application in cooked meat. Foods 9:359. https://doi.org/10.3390/foods9030359.

Gurtler, J. B., J. L. Kornacki, and L. R. Beuchat. 2005. Enterobacter sakazakii: A coliform of increased concern to infant health. Int. J. Food Microbiol. 104:1-34. https://doi.org/10.1016/j.ijfoodmicro .2005.02.013.

Henry, M., and A. Fouladkhah. 2019. Outbreak history, biofilm formation, and preventive measures for control of Cronobacter sakazaki in infant formula and infant care settings. Microorganisms 7:77. https://doi.org/10.3390/microorganisms7030077.

Joseph, S., P. Desai, Y. Ji, C. A. Cummings, R. Shih, L. Degoricija, A. Rico, P. Brzoska, S. E. Hamby, N. Masood, S. Hariri, H. Sonbol, N. Chuzhanova, M. McClelland, M. R. Furtado, and S. J. Forsythe. 2012. Comparative analysis of genome sequences covering the seven Cronobacter species. PLoS One 7:e49455. https://doi .org/10.1371/journal.pone.0049455.

Joshi, S. S., A. B. Howell, and D. H. D'Souza. 2014. Cronobacter sakazakii reduction by blueberry proanthocyanidins. Food Microbiol. 39:127-131. https://doi.org/10.1016/j.fm.2013.11.002.

Kim, H., J.-H. Ryu, and L. R. Beuchat. 2006. Attachment of and biofilm formation by Enterobacter sakazakii on stainless steel and en- 
teral feeding tubes. Appl. Environ. Microbiol. 72:5846-5856. https: //doi.org/10.1128/AEM.00654-06.

Kim, N. N., W. J. Kim, and S. S. Kang. 2019. Antibiofilm effect of crude bacteriocin derived from Lactobacillus brevis DF01 on Escherichia coli and Salmonella Typhimurium. Food Control 98:274-280. https://doi.org/10.1016/j.foodcont.2018.11.004.

Kuete, V., S. Alibert-Franco, K. O. Eyong, B. Ngameni, G. N. Folefoc, J. R. Nguemeving, J. G. Tangmouo, G. W. Fotso, J. Komguem, B. M. W. Ouahouo, J.-M. Bolla, J. Chevalier, B. T. Ngadjui, A. E. Nkengfack, and J.-M. Pagès. 2011. Antibacterial activity of some natural products against bacteria expressing a multidrug-resistant phenotype. Int. J. Antimicrob. Agents 37:156-161. https://doi .org/10.1016/j.ijantimicag.2010.10.020.

Lambert, R. J., P. N. Skandamis, P. J. Coote, and G. J. Nychas. 2001. A study of the minimum inhibitory concentration and mode of action of oregano essential oil, thymol and carvacrol. J. Appl. Microbiol. 91:453-462. https://doi.org/10.1046/j.1365-2672.2001 .01428.x

Li, R., P. Fei, C. X. Man, B. B. Lou, J. T. Niu, J. Feng, L. H. Sun, M. Y. Li, and Y. J. Jiang. 2016. Tea polyphenols inactivate Cronobacter sakazakii isolated from powdered infant formula. J. Dairy Sci. 99:1019-1028. https://doi.org/10.3168/jds.2015-10039.

Lu, Y., P. Liu, C. Li, M. Sha, J. Fang, J. Gao, X. Xu, and K. R. Matthews. 2019. Prevalence and genetic diversity of Cronobacter species isolated from four infant formula production factories in China. Front. Microbiol. 10:1938. https://doi.org/10.3389/fmicb .2019.01938.

Maiyo, Z. C., R. M. Ngure, J. C. Matasyoh, and R. Chepkorir. 2010. Phytochemical constituents and antimicrobial activity of leaf extracts of three Amaranthus plant species. Afr. J. Biotechnol. 9:3178-3182.

Meireles, A., E. Giaouris, and M. Simoes. 2016. Alternative disinfection methods to chlorine for use in the fresh-cut industry. Food Res. Int. 82:71-85. https://doi.org/10.1016/j.foodres.2016.01.021.

Park, S. Y., M. F. R. Mizan, and S. D. Ha. 2016. Inactivation of Cronobacter sakazakii in head lettuce by using a combination of ultrasound and sodium hypochlorite. Food Control 60:582-587. https://doi.org/10.1016/j.foodcont.2015.08.041.

Di Pasqua, R., G. Mamone, P. Ferranti, D. Ercolini, and G. Mauriello. 2010. Changes in the proteome of Salmonella enterica serovar Thompson as stress adaptation to sublethal concentrations of thymol. Proteomics 10:1040-1049.

Peter, K., and P. Gandhi. 2017. Rediscovering the therapeutic potential of Amaranthus species: A review. Egypt. J. Basic Appl. Sci. 4:196-205. https://doi.org/10.1016/j.ejbas.2017.05.001.

Shi, C., S. Kaikuo, Z. Xiaorong, S. Yi, S. Yue, C. Yifei, J. Zhenyu, S. Huihui, S. Zheng, and X. Xiaodong. 2016a. Antimicrobial activity and possible mechanism of action of citral against Cronobacter sakazakii. PLoS One 11:e0159006. https://doi.org/10.1371/journal .pone.0159006

Shi, C., K. Song, X. Zhang, Y. Sun, Y. Sui, Y. Chen, Z. Jia, H. Sun, Z. Sun, and X. Xia. 2016b. Antimicrobial effect of lipoic acid against
Cronobacter sakazakii. Food Control 59:352-358. https://doi.org/ 10.1016/j.foodcont.2015.05.041.

Shi, C., Y. Sun, Z. Zheng, X. Zhang, K. Song, Z. Jia, Y. Chen, M. Yang, X. Liu, R. Dong, and X. Xia. 2016c. Antimicrobial activity of syringic acid against Cronobacter sakazakii and its effect on cell membrane. Food Chem. 197:100-106. https://doi.org/10.1016/j .foodchem.2015.10.100.

Sonbol, H., S. Joseph, C. M. McAuley, H. M. Craven, and S. J. Forsythe. 2013. Multilocus sequence typing of Cronobacter spp. from powdered infant formula and milk powder production factories Int. Dairy J. 30:1-7. https://doi.org/10.1016/j.idairyj.2012.11.004.

Wang, L. H., Z. H. Zhang, X. A. Zeng, D. M. Gong, and M. S. Wang. 2017. Combination of microbiological, spectroscopic and molecular docking techniques to study the antibacterial mechanism of thymol against Staphylococcus aureus: Membrane damage and genomic DNA binding. Anal. Bioanal. Chem. 409:3055. https://doi.org/10 .1007/s00216-017-0264-3.

Wu, S., Y. Jiang, B. Lou, J. Feng, Y. Zhou, L. Guo, S. J. Forsythe, and C. Man. 2018. Microbial community structure and distribution in the air of a powdered infant formula factory based on cultivation and high-throughput sequence methods. J. Dairy Sci. 101:69156926. https://doi.org/10.3168/jds.2017-13968.

Wu, K., Y. Lin, X. Chai, X. Duan, X. Zhao, and C. Chun. 2019. Mechanisms of vapor-phase antibacterial action of essential oil from Cinnamomum camphora var. linaloofera Fujita against Escherichia coli. Food Sci. Nutr. 7:2546-2555. https://doi.org/10.1002/ fsn3.1104.

Xiang, J., F. B. Apea-Bah, V. U. Ndolo, M. C. Katundu, and T. Beta. 2019. Profile of phenolic compounds and antioxidant activity of finger millet varieties. Food Chem. 275:361-368. https://doi.org/ 10.1016/j.foodchem.2018.09.120.

Xu, Y. F., C. Shi, Q. Wu, Z. W. Zheng, P. F. Liu, G. H. Li, X. L. Peng, and X. D. Xia. 2017. Antimicrobial activity of punicalagin against Staphylococcus aureus and its effect on biofilm formation. Foodborne Pathog. Dis. 14:282-287. https://doi.org/10.1089/fpd .2016 .2226 .

Yemis, G. P., S. Bach, and P. Delaquis. 2019. Antibacterial activity of polyphenol-rich pomegranate peel extract against Cronobacter sakazakii. Int. J. Food Prop. 22:985-993. https://doi.org/10.1080/ 10942912.2019.1622564.

\section{ORCIDS}

Peng Fei ำ https://orcid.org/0000-0001-7895-4603

Hongxia Feng (®) https://orcid.org/0000-0002-9781-0282

Yunhe Chang $\odot$ https://orcid.org/0000-0002-4593-4486

Ling Guo 누 https://orcid.org/0000-0002-5743-098X

Junliang Chen (ㄴ) https://orcid.org/0000-0001-9452-4697 